A. O. Bondarenko, Dr. Sc. (Tech.), Assoc. Prof., orcid.org/0000-0002-7666-6752
National Mining University, Dnipro, Ukraine, e-mail: Bondarenkoa@nmu.org.ua

\title{
THEORETICAL BASES OF PULP SUCTION PROCESS IN THE SHALLOW DREDGE UNDERWATER FACE
}

Purpose. To develop a mathematical model of the process of interaction of the shallow dredge suction pipe with solid particles and formation of the underwater face.

Methodology. To describe the motion of a fluid flow involving solid particles in the underwater face of a single suction pipe, the continuity equation for an ideal fluid in polar coordinates is applied. The solution of the differential equation in general form is fulfilled. The motion of solid particles and the formation of an underwater face of the suction pipe are considered as a result of the difference in pressures below and above the particle.

Findings. A mathematical description of the process of movement of a carrier flow carrying solid particles in the underwater surface suction zone of a single suction pipe is performed, using the continuity equation for an ideal fluid, written in polar coordinates. The interaction of the suction pipe with the pulp flow is described in the form of an axisymmetric process with a function of the medium density constant in time. The motion of a solid particle in an underwater face of a suction pipe is considered as a function of the difference in pressures below and above the particle. Based on the fact of low velocities of the suction flow moving, an expression is obtained for calculating the suction radius of solid particles and determining the boundary of the erosion zone when the soil is sucked in the underwater face of the suction pipe. The determining effect of the radial motion of the suction flow and the centrifugal force insignificance is taken into account. The construction of an underwater surface erosion zone of a single suction pipe in the form of surfaces of the erosion zone boundary and the boundary of the suction zone of the suspended soil composed of quartz particles by the size $0.16 \mathrm{~mm}$ at a suction efficiency of $800 \mathrm{~m}^{3} / \mathrm{h}$ is constructed.

Originality. As a result of the development of a mathematical model on the basis of the equation of continuity written in polar coordinates, it is established that the radius of absorption of suspended quartz particles by the size $d=$ $=0.15 \ldots . .5 \mathrm{~mm}$ in the underwater face of a single suction pipe is directly proportional to the root of the fourth ratio of the square of the productivity of the pulp in the suction pipe to the solid particle diameter and the cosine of the inclination angle of forming of the suction zone.

Practical value. The analytical dependencies obtained in the work allow us to perform the construction of the boundaries of the underwater surface face and determine the volume of granular soils excavation by the shallow dredge working member. That allows substantiating the rational design parameters of the mining machine and the technological parameters of the process of mineral resources underwater mining.

Keywords: shallow dredge, underwater face, washing out, suction

Introduction. In accordance with general concepts, there are three modes of disjointed soils suction in hydromechanized underwater mining: surface, deep and mixed [1, 2]. Modern complexes for hydromechanized mining and processing of disjointed granular minerals perform mining operations from depths of up to $50 \mathrm{~m}$ with a volumetric pulp concentration of up to $30 \%$ [3, 4]. In this case, the most common is the surface suction of solid ground particles with the formation of an underwater surface erosion zone (Fig. 1). One of the main parameters in the technology of underwater extraction of disjointed soils is the distance from the dredge suction pipe to the surface of the underwater face. The installation and retention of the suction pipe at the required distance from the face allows the maximum efficiency of the suction process of the granular material. The use of disintegrators changes the mode of interaction between the suction pipe and the solid particles, which requires an additional mathematical description.

Analysis of the recent research and publications. The free suction of the previously undisturbed granular mineral with the formation of an underwater surface erosion zone is a fairly well-studied process that is described as

(C) Bondarenko A. O., 2018 the movement of solids to the suction pipe as part of a carrier fluid flow from an unrestricted water space. In addition the solids are separated from the solid soil while flowing along liquid stream at velocities exceeding the value of washing speed, which is a function of hard particles size. Thus, a submarine wash zone is formed, whose dimensions are limited by the values of the washing speed at its surface [5]. However, preliminary loosening of the soil massif with the separation of solid particles and forced displacement of them into the carrier pulp flow changes the regime of formation of the surface washing out zone [6]. The suction of the pre-washed ground can be described as the transport of hard particles in the pulp to the suction pipe, under the influence of the pressure difference in the surrounding water space and the suction pipe. At the same time, the dimensions of such a loosening zone are limited by the values of the hydraulic size of the hard particles, of which the face is folded.

Based on the results of previous studies, including observations of the process of pulp suction in laboratory conditions, the scheme of the process of interaction of the suction pipe with hard particles, both in the composition of the disjointed massif and in the suspended state in the carrier pulp flow, is rationally represented in the 


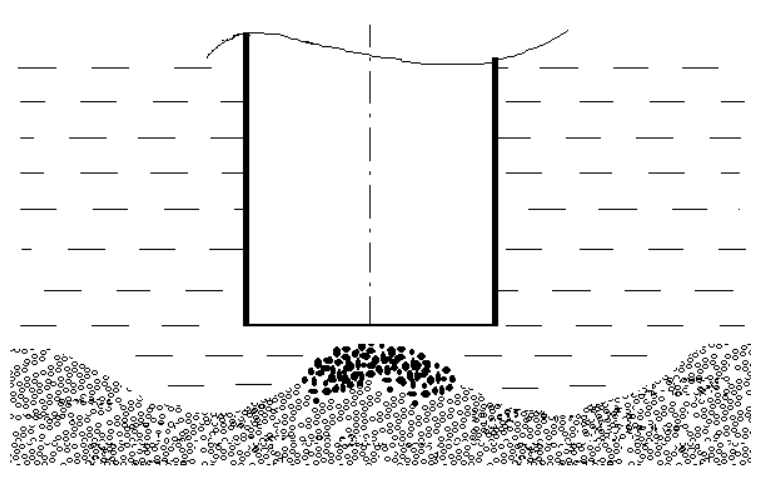

Fig. 1. Suction scheme for disjointed soil in the underwaterface

form (Fig. 2) [7, 8]. The characteristic areas of this process are: the sedimentation zone of the washing out zone 2 , the soil suction washing out zone 3 , the washing out zone boundary 4 , the sedimentation zone of the suspended soil suction zone 5 , the suction zone of the suspended soil 6 , the suction boundary of the suspended soil 7. Determination of the suction boundary of the suspended soil is an important scientific and technical task, whose solution will allow rationalizing the processes of ground preparation in the underwater face for their mining.

Unsolved aspects of the problem. The distance from the suction pipe section to the suction zone boundary of the particles in question moving at a speed $U_{g r}$ in the underwater face, measured along the forming a suction zone characterized by an inclination angle $\psi$ call it the suction radius of a particle in an underwater face.

Determination of the value of the particle suction radius will allow us to solve the problem of constructing the boundaries of the suction zone for particles of different density and size, that is, constructing the pulp suction field in the underwater face.

A correct description of the interaction process between the shallow dredge suction pipe and solid particles in the pulp flow in an underwater surface face requires the development of a mathematical model of flow motion in the erosion areas during suction of disjointed soil and suction of the suspended soil. In connection with this, the development of the theoretical foundations of the process of interaction between the suction pipe and the pulp flow in these areas is an important and urgent scientific and technical task, the solution of which will allow us to substantiate the rational parameters of the shallow dredge dredging equipment.

Objectives of the article. The purpose of this work is to develop a mathematical model of the process of interaction between the shallow dredge suction pipe with hard particles and the formation of an underwater face. The use of such a model in engineering calculations will allow us to substantiate the rational design and technological parameters of shallow dredges dredging equipment and establish the underwater face boundaries by constructing the surface of the suspended soil suction zone, as a result of which we determine the volume of soil extracted by a single suction pipe.

Description of the research methodology. The process of interaction of the suction pipe of the dredge with the pulp flow, which includes solid ground particles formed during the motion of liquid from an unlimited bottomhole space, is considered. To describe the motion of a fluid flow involving hard particles in the underwater face of a single suction pipe, the continuity equation for an ideal liquid in polar coordinates is applied. The solution of the differential equation in general form is fulfilled. The motion of hard particles and the formation of an underwater face of the suction pipe are considered as a result of the difference in pressures below and above the particle.

Presentation of the main research and explanation of scientific results. For the mathematical description of the process, we introduce the following notations (Fig. 3): $Q-$ is productivity of the suction pulp, $\mathrm{m}^{3} / \mathrm{s}$; $r-$ is the distance from the suction pipe to the suction area boundary, $\mathrm{m} ; r_{s p}-$ is the radius of the suction pipe, $\mathrm{m} ; u_{r}-$ is the radial velocity of the suction flow, $\mathrm{m} / \mathrm{s}$; $u_{\psi}-$ is the tangential flow velocity, $\mathrm{m} / \mathrm{s} ; U_{w}-$ is the soil washing speed on the inclined forming line of the washing out zone, $\mathrm{m} / \mathrm{s} ; \theta-$ is the angle of the suction line inclination in the $X-Z$ plane; $\psi-$ is the angle of the suc-

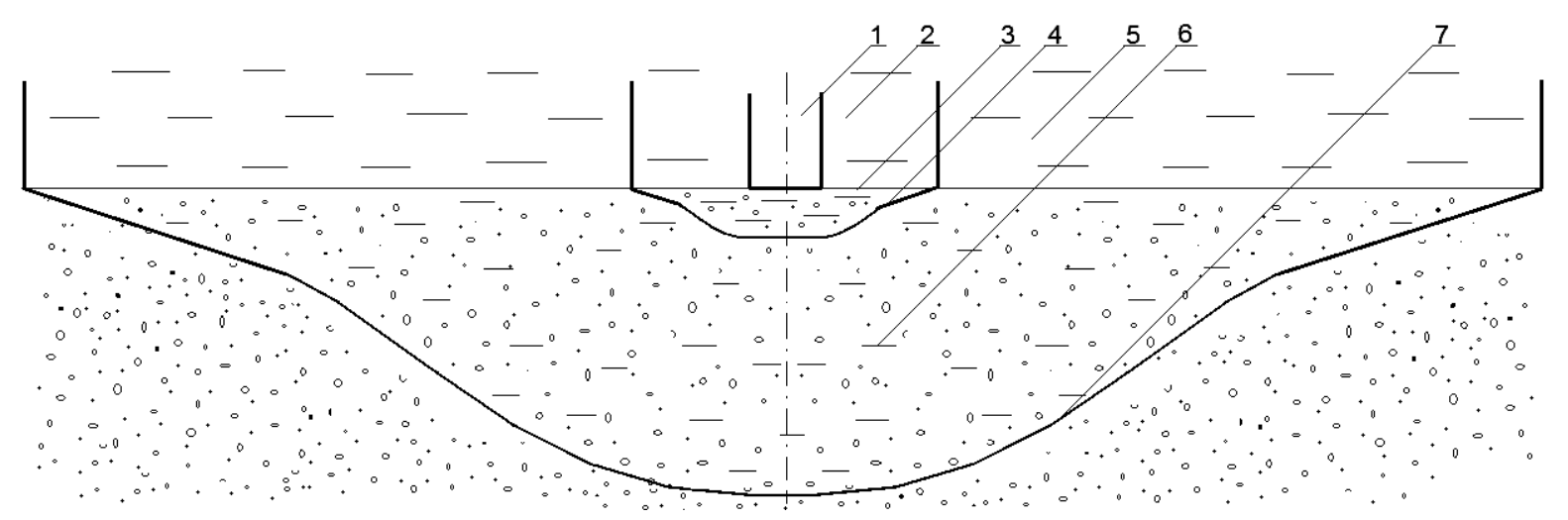

Fig. 2. Scheme of the soil suction process in the underwater face [8]:

1 - suction pipe; 2 - sedimentation zone of the washing out zone; 3 - the soil suction washing out zone; 4 - the washing out zone boundary; 5 - the sedimentation zone of the suspended soil suction zone; 6 - the suction zone of the suspended soil; 7-the suction boundary of the suspended soil 


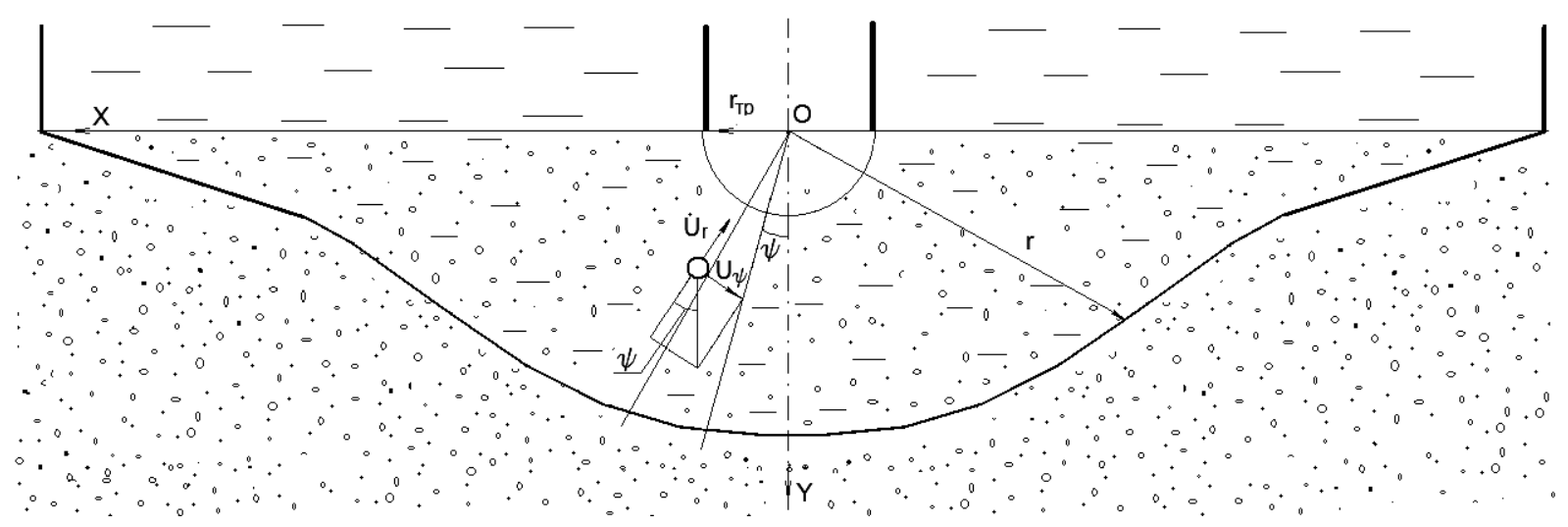

Fig. 3. The design scheme of the interaction process of a single suction pipe with suction pulp in an underwater face

tion line rotation in the $\mathrm{X}-\mathrm{Y}$ plane, it should be taken from $0.01 \pi$ to $\pi / 2$.

In view of the low flow velocities in the suction area, we simplify the liquid motion description to the exclusion of centrifugal forces and vortex flows. The fluid flow in the underwater face of a single suction pipe is described by applying the continuity equation for an ideal (inviscid) liquid, which in polar coordinates is written as

$$
\begin{gathered}
\frac{\partial \rho}{\partial t}+\frac{1}{r^{2}} \frac{\partial\left(\rho u_{r} r^{2}\right)}{\partial r}+\frac{1}{r \sin \psi} \frac{\partial\left(\rho u_{\psi} \sin \psi\right)}{\partial \psi}+ \\
+\frac{1}{r \sin \psi} \frac{\partial\left(\rho u_{\theta}\right)}{\partial \theta}=0 .
\end{gathered}
$$

Let us assume that the process of interaction of the suction pipe with the flow of pulp, including hard particles, proceeds axially symmetrically about the axis of the suction pipe, in this case it is rational to simplify the mathematical description of the process before solving the plane problem, and then the continuity equation takes the form

$$
\frac{\partial \rho}{\partial t}+\frac{1}{r^{2}} \frac{\partial\left(\rho u_{r} r^{2}\right)}{\partial r}+\frac{1}{r \sin \psi} \frac{\partial\left(\rho u_{\psi} \sin \psi\right)}{\partial \psi}=0
$$

We simplify the description of the process under consideration until there is no change in the density function in the suction flow in time, in this case the equation of continuity is reduced to the form

$$
\frac{1}{r^{2}} \frac{\rho \partial\left(u_{r} r^{2}\right)}{\partial r}+\frac{1}{r \sin \psi} \frac{\rho \partial\left(u_{\psi} \sin \psi\right)}{\partial \psi}=0,
$$

and after the transformations it is

$$
\frac{\partial\left(u_{\psi} \sin \psi\right)}{\partial \psi}=-\frac{\sin \psi}{r} \frac{\partial\left(u_{r} r^{2}\right)}{\partial r} .
$$

Knowing that on the boundary of the suction area the tangential flow velocity $u_{\psi}$ is equal to the washing speed $U_{w}$, i. e. $u_{\psi}=U_{w}$ we write the equation of continuity as

$$
\frac{\partial\left(u_{w} \sin \psi\right)}{\partial \psi}=-\frac{\sin \psi}{r} \frac{\partial\left(u_{r} r^{2}\right)}{\partial r}
$$

and after transformations we reduce it to the form

$$
u_{w} \cos \psi=-\frac{\sin \psi}{r}\left(r^{2} \frac{\partial\left(u_{r}\right)}{\partial r}+u_{r} 2 r\right) .
$$

Hence, the expression for determining the function of variation of the radial velocity of the suction stream $u_{r}$ along the radius $r$ is written as

$$
\frac{\partial\left(u_{r}\right)}{\partial r}=-\frac{u_{w} \cos \psi}{r \sin \psi}+\frac{2 u_{r} \sin \psi}{r \sin \psi},
$$

and after transformations we simplify it to the form

$$
\frac{\partial\left(u_{r}\right)}{\partial r}=\frac{1}{r}\left(2 u_{r}-u_{w} \operatorname{ctg} \psi\right) .
$$

For further transformations we use the well-known formula for determining the mean velocity of a liquid flow motion

$$
u_{r}=\frac{Q}{4 \pi r^{2}}
$$

Then the expression for determining the dependence of the suction stream radial velocity $u_{r}$ of the radius $r$ is written as

$$
\frac{\partial\left(u_{r}\right)}{\partial r}=\frac{1}{r}\left(2 \frac{Q}{4 \pi r^{2}}-u_{w} \operatorname{ctg} \psi\right) .
$$

Hence the flow velocity is obtained as a function of

$$
u_{r}=\frac{Q}{4 \pi} \int_{0}^{r} \frac{d r}{r^{3}}-u_{w} \operatorname{ctg} \psi \int_{0}^{r} \frac{d r}{r}+C .
$$

After taking the integrals, we give the formula for determining the radial velocity the form

$$
u_{r}=-\frac{Q}{4 \pi r^{2}}-u_{w} \operatorname{ctg} \psi \ln (r)+C
$$

To determine the integration constant $C$, we use the initial suction condition when $u_{r}=\frac{Q}{2 \pi r_{s p}^{2}}$, in this case, after the transformations, we obtain 


$$
C=\frac{3}{4} \frac{Q}{\pi r_{s p}^{2}}+u_{w} \operatorname{ctg} \psi \ln \left(r_{s p}\right) .
$$

Then, substituting the expression for the integration constant $\mathrm{C}$ in the formula for determining the radial velocity

$$
\frac{Q}{4 \pi r^{2}}=-\frac{Q}{4 \pi r^{2}}+\frac{3}{4} \frac{Q}{\pi r_{s p}^{2}}+u_{w} \operatorname{ctg} \psi \ln \left(r_{s p}\right)-u_{w} \operatorname{ctg} \psi \ln (r),
$$

and, after the transformations it is

$$
\frac{Q}{4 \pi}\left[\frac{3}{r_{s p}^{2}}-\frac{2}{r^{2}}\right]+u_{w} \operatorname{ctg} \psi \ln \frac{r_{s p}}{r}=0 .
$$

Solving the obtained expression for known values of the suction pipe radius $r_{s p}$, soil washing speed on the washing out zone inclined forming line $U_{w}$ and the angle of inclination of the suction line $\psi$ it is possible to determine the function of the suction radius, i.e., changing the distance from the suction pipe to the suction area boundary.

The motion of a hard particle in the underwater face of the suction pipe can be ensured by the difference in pressures below and above the particle. If there is more pressure under the particle than above it, then the particle moves to the suction pipe, if on the contrary the particle moves to the side opposite to it. If the pressure under the particle is equal to the pressure above the particle, then it maintains its equilibrium and is at the boundary of the suction area.

Let us consider the movement of the fluid flow in the suction area of the suction pipe underwater face. It is known that the suction flow performs both radial and rotational motion [9]. At the same time, the radial movement ensures the proper capacity $Q$, and the rotational motion leads to the appearance of centrifugal forces, and, correspondingly, to a decrease in the suction radius $r$.

The pressure acting on a hard particle can be obtained from such an expression, $\mathrm{Pa}$

$$
P=P_{0}+P_{c f}-P_{v h}
$$

where $P_{0}$ is hydrostatic pressure, $\mathrm{Pa} ; P_{s f}$ is the pressure caused by centrifugal force, $\mathrm{Pa} ; P_{v h}$ is the pressure caused by the effect of velocity head, $\mathrm{Pa}$.

At the boundary of the suction area, in the absence of fluid flow movement, the pressure corresponds to the hydrostatic pressure, $\mathrm{Pa}$

$$
P_{0}=P_{a t m}+\rho g h
$$

where $P_{a t m}$ is the atmospheric pressure, $\mathrm{Pa} ; \rho$ is the density of liquid in the underwater face suction area, $\mathrm{kg} / \mathrm{m}^{3}$; $h$ is the depth of immersion of a hard particle, $\mathrm{m}$.

Taking the design scheme (Fig. 3) as a basis, the depth of placement of the hard particle is obtained from the expression, $\mathrm{m}$

$$
h=h_{0}+r \cos \psi,
$$

where $h_{0}$ is the depth of suction pipe immersion, $\mathrm{m}$.
Using expressions $(2,3)$, we obtain a formula for determining the hydrostatic pressure acting on the suction area boundary

$$
P_{0}=P_{a t m}+\rho g h_{0}+\rho g r \cos \psi .
$$

It is known that the pressure caused by the effect of the velocity head can be expressed by the formula, $\mathrm{Pa}$

$$
P_{v h}=\rho \frac{U_{\mathrm{sp}}^{2}}{2} .
$$

We represent the velocity of the fluid in the suction pipe $U_{s p}$ in the form of a known dependence, $\mathrm{m} / \mathrm{s}$

$$
U_{s p}=\frac{Q}{2 \pi r_{s p}^{2}}
$$

Then the formula for determining the pressure $P_{v h}$ at the level of the suction pipe will take this form, $\mathrm{Pa}$

$$
P_{v h . s p}=\rho \frac{Q^{2}}{8 \pi^{2} r_{s p}^{4}}
$$

At the same time, the pressure $P_{v h}$ at any distance from the suction pipe can be obtained from the expression, $\mathrm{Pa}$

$$
P_{v h}=\rho \frac{Q^{2}}{8 \pi^{2} r^{4}}
$$

To determine the influence of the centrifugal force on the fluid motion in the suction area, we use the dependence

$$
P_{c f}=\rho \frac{U_{\tau}^{2}}{2}
$$

Having obtained the expressions (1-7), we write the formula for determining the pressure acting on a hard particle in the suction pipe underwater face

$$
P=P_{a t m}+\rho g h_{0}+\rho g r \cos \psi+\rho \frac{U_{\tau}^{2}}{2}-\rho \frac{Q^{2}}{8 \pi^{2} r^{4}} .
$$

We get the pressure difference under the hard particle and above it, which will cause its motion, taking the dependences $(6,7)$ as a basis, then

$$
\Delta P=P_{v h}-P_{c f}=\rho\left(\frac{Q^{2}}{8 \pi^{2} r^{4}}-\frac{U_{\tau}^{2}}{2}\right) .
$$

Let us consider the force interaction when sucking in hard particles in the suction pipe underwater face (Fig. 4). A solid particle in an underwater face is affected by the following forces: gravity, the force of adhesion to the soil mass, the force due to the difference in pressure under and above the hard particle. Gravity, taking into account the strength of Archimedes, $\mathrm{H}$

$$
F_{g}^{n}=\left(\rho_{s k}-\rho_{w}\right) \frac{\pi d^{3}}{6} g \cos \psi,
$$




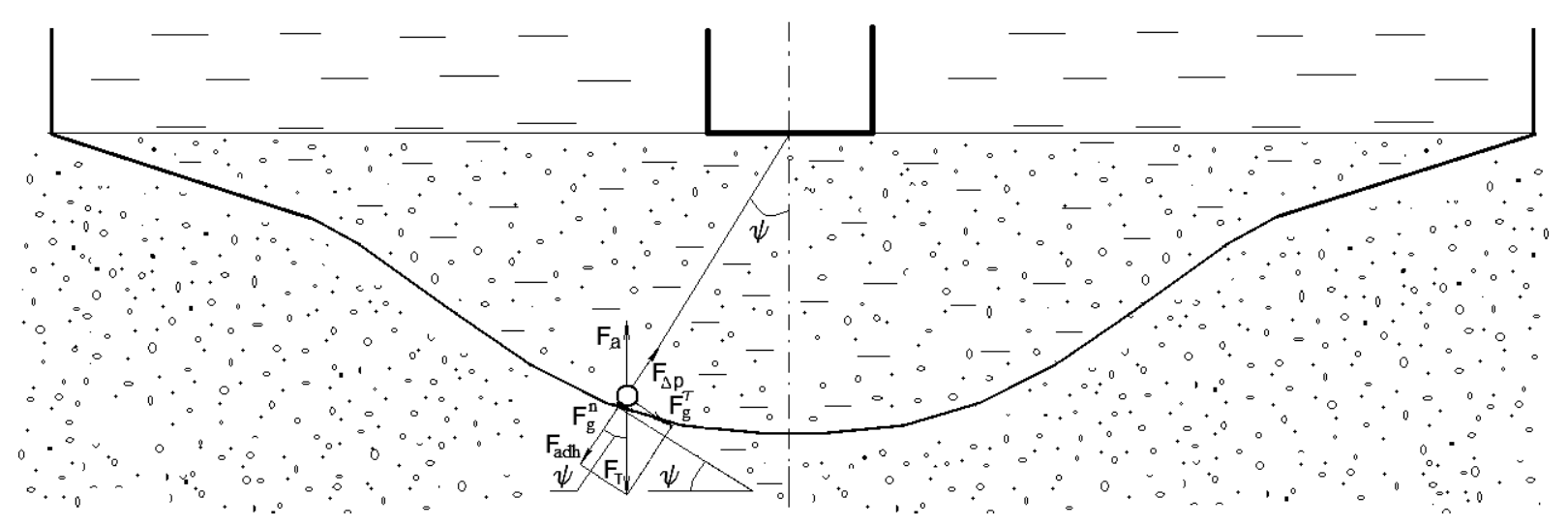

Fig. 4. The design diagram of forces acting on a hard particle in an underwater face [8]

where $\rho_{s k}$ is the density of the soil skeleton, $\mathrm{kg} / \mathrm{m}^{3} ; d$ is the particle diameter, $\mathrm{m} ; \rho_{w}$ is the density of the medium (water), $\mathrm{kg} / \mathrm{m}^{3}$.

The strength of the cohesion of a hard particle with the soil massive can be expressed as, $\mathrm{H}$

$$
F_{a d h}=K_{a d h} \frac{\pi d^{2}}{4},
$$

where $K_{\text {adh }}$ is the coefficient of adhesion, $\mathrm{N} / \mathrm{m}^{2}$.

The force due to the difference in pressure, $\mathrm{H}$

$$
F_{\Delta p}=\Delta P \frac{\pi d^{2}}{4},
$$

where $\Delta P$ is the pressure difference, at the suction area boundary, Pa.

The equilibrium state for a hard particle will be observed when the forces acting on it are equal, that is,

$$
F_{\Delta p}=F_{g}^{n}+F_{a d h} .
$$

Then substituting the expressions for the corresponding forces from formulas (8-11) into the dependence obtained, we write the formula for the equilibrium state in the form

$\rho_{q}\left(\frac{Q^{2}}{8 \pi^{2} r^{4}}-\frac{U_{\tau}^{2}}{2}\right) \frac{\pi d^{2}}{4}=\left(\rho_{s k}-\rho_{w}\right) \frac{\pi d^{3}}{6} g \cos \psi+K_{a d h} \frac{\pi d^{2}}{4}$.

Performing simple transformations, we write down the basic expression for calculating the suction radius of hard particles in the suction pipe underwater face, $\mathrm{m}$

$$
r=\sqrt[4]{\frac{Q^{2}}{8 \pi^{2}\left[\frac{U_{\tau}^{2}}{2}+\left(\frac{\rho_{s k}}{\rho_{w}}-1\right) \frac{2 d}{3} g \cos \psi+\frac{1}{\rho_{w}} K_{s k}\right]}} .
$$

In view of the small velocities of the suction flow, especially, for example, at the boundary of the suspended soil suction zone, let us assume that the decisive factor is the radial motion of the flow, and the effect of the centrifugal forces is negligible, then the expression for calculating the suction radius of hard particles for determining the boundary of the washing zone when the soil is absorbed in the suction pipe underwater face, is written as, $\mathrm{m}$

$$
r_{\delta}=\sqrt[4]{\frac{Q^{2}}{8 \pi^{2}\left[\left(\frac{\rho_{s k}}{\rho_{w}}-1\right) \frac{2 d}{3} g \cos \psi+\frac{1}{\rho_{w}} K_{s k}\right]}} .
$$

To determine the boundaries of the suspended soil suction zone, the adhesion forces need not be taken into account, then the formula for determining the suction radius in the suction pipe underwater face will take the form, $m$

$$
r_{s}=\sqrt[4]{\frac{Q^{2}}{8 \pi^{2}\left(\frac{\rho_{s k}}{\rho_{w}}-1\right) \frac{2 d}{3} g \cos \psi}}
$$

The boundaries of the suction zone of suspended quartz particles with density $\rho_{s k}=2650 \mathrm{~kg} / \mathrm{m}^{3}$ are defined by simplifying the process to the motion of hard particles in water with density $\rho_{w}=1000 \mathrm{~kg} / \mathrm{m}^{3}$, then the expression (12) can be written as, $m$

$$
r_{s}^{q}=0.335 \cdot \sqrt[4]{\frac{Q^{2}}{d g \cos \psi}}
$$

Analyzing the obtained dependences, we construct graphs of the change in the values of the suction radius for the washout zone $r_{w}^{q}$ and suction zones of the suspended soil $r_{s}^{q}$ when the quartz particles in size $d=$ $=0.16 \mathrm{~mm}$ are sucked, having a fixed suction capacity of $800 \mathrm{~m}^{3} / \mathrm{h}$ (Figs. $5, a, b$ ). In the first case, the adhesion of hard particles to the massif is taken into account $K_{a d h}=$ $=50 \mathrm{~N} / \mathrm{m}^{2}$ (Fig. 5, a). In the second case, when the washed out soil is sucked in, the adhesion of hard particles to the mass is not taken into account. In this case, as can be seen from the graph (Fig. 5, b), the values of the suction radius $r_{s}^{q}$ are greater, and the graph itself has a more sloping area of extremum.

Having the values of the suction radius, it is possible to construct boundaries for these areas for the washing out zone $r_{w}$ and suction zones $r_{s}$. An example of constructing the boundary of the suction zone for quartz particles of size $d=0.16 \mathrm{~mm}$ with a suction capacity of $800 \mathrm{~m}^{3} / \mathrm{h}$ is shown in Figs. 6 and 7. It is noticeable that the boundary of the suction areas has a characteristic shape with a flat extremum, in its lower part, i.e. under 


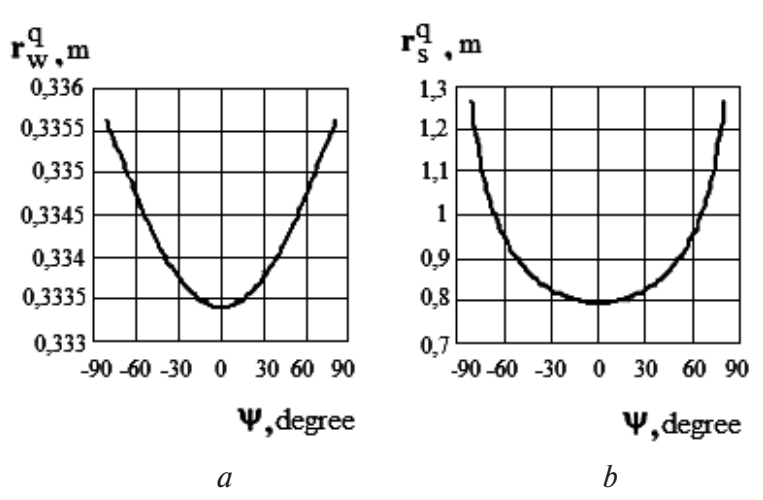

Fig. 5. Graphical presentation of the dependence of the suction radius on the inclination angle of the suction area forming at a suction capacity of $800 \mathrm{~m}^{3} / \mathrm{h}$

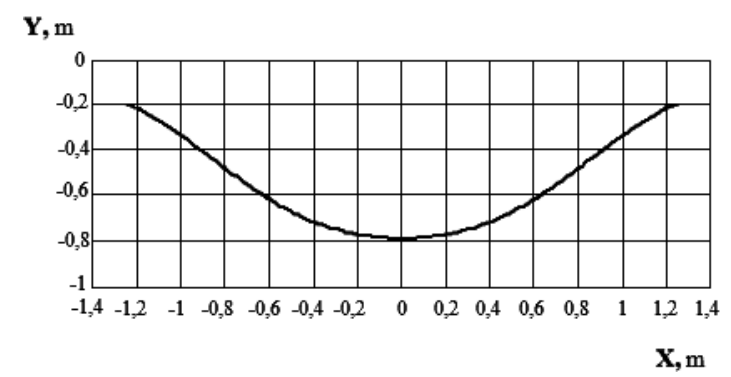

Fig. 6. Graphical representation of the suction zone boundaries of quartz particles with a particle size of $0.16 \mathrm{~mm}$ at a suction capacity of $800 \mathrm{~m}^{3} / \mathrm{h}$

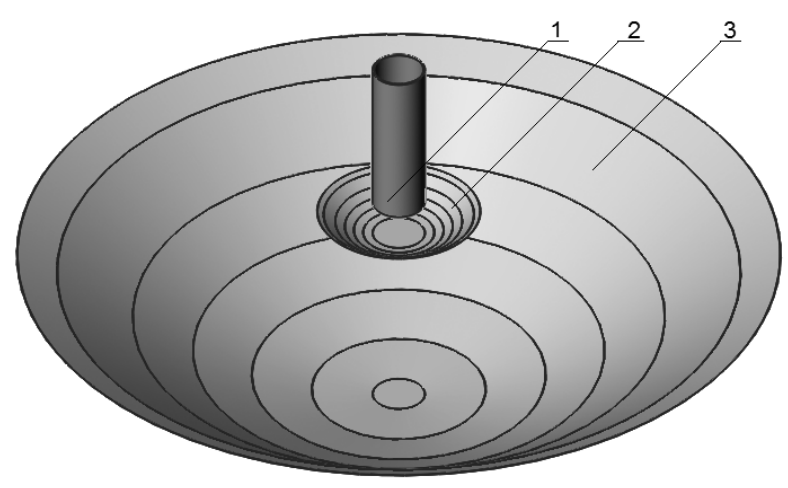

Fig. 7. Graphical presentation of the suction zone boundaries of quartz particles with a particle size of $0.16 \mathrm{~mm}$ at a suction capacity of $800 \mathrm{~m}^{3} / \mathrm{h}$ :

1 - suction pipe; 2 - the washing out zone boundary; 3 the suction boundary of the suspended soil

a suction pipe, and tending to infinity at its upper portion with increasing angle $\psi$ of up to $90^{\circ}$ (Fig. 6).

The resulting theoretical description of force interaction at the suction of hard particles in the underwater surface suction pipe face the suction area boundaries differs from the form of the surface face, obtained in earlier studies (Fig. 1). Such a difference in the shape of the surface face is explained by the fact that Fig. 6 shows the boundary surface of the suction area of hard particles particulate fixed size, e.g. $d=0.16 \mathrm{~mm}$. Fig. 1 shows the shape of the underwater surface suction pipe face in the massive folded with hard particles of varying size and density. Considering formation of underwater surface suction pipe face with hard particles of the same density, such as silica particles, it is understood that the diameter of the hard particles has a determining influence on the value of the radius of suction, and hence on the dimensions of the suction zone. Directly under the suction pipe, i.e. in the central portion of the surface of the underwater surface suction pipe face, there accumulate hard particles, which, due to large size or density, are outside the respective suction area.

Conclusions and recommendations for further research. As a result of development of the mathematical model of interaction of shallow dredge suction pipe with hard particles in the characteristic areas of the surface of the underwater surface suction pipe face, an analytical relationship is obtained, which allows estimating the change of the distance from the suction pipe to suction area boundary. It is found that the radius of the suspended particles of quartz particles with size $d=0.15 \ldots$ $5 \mathrm{~mm}$ in the underwater single suction pipe face is directly proportional to the fourth root of a square power of the ratio of performance of the pulp in the suction pipe to the diameter of the hard particles and the estimated cosine of the inclination angle of the suction zone forming.

Project name and number, in which the obtained results are presented. The work relates to the scientific direction of the Department of Mining Machines and Engineering of SHEE "National Mining University" and is performed as part of state budget theme GP-452 (0112U000871) "Development of theoretical foundations for the creation and optimization of modern mining equipment parameters for underwater extraction of minerals".

\section{References.}

1. Peter Albers, 2010. Motion control in offshore and dredging. Springer Science Business Media B.V. Available at: <https://books.google.com.ua/books?id=2SAJEAB 5 aqkC\&printsec $=$ frontcover $\& \mathrm{dq}=$ Motion + control + in + offshore + and + dreing $\&$ hl $=$ ru\&sa $=X \& v e d=0$ ahUKE wiAwrzQ88PaAhWHVywKHXOZBSsQ6AEIJjAA\#v= onepage \&q $=$ Motion $\% 20$ control\% 20 in $\% 20$ offshore $\% 20$ and $\% 20$ dredging $\& \mathrm{f}=$ false $>$ [Accessed 12 April 2017].

2. Volker Patzold, Gunter Gruhn and Carsten Drebenstedt, 2008. Der Nassabbau. Erkundung, Gewinnung, Aufbereitung, Bewertung/Springer-Verlag Berlin Heidelberg. Available at: <https://books.google.com.ua/books $? \mathrm{id}=$ CqsfBAAAQBAJ $\&$ printsec $=$ frontcover $\& \mathrm{dq}=$ Der +Nassabbau.+Erkundung, + Gewinnung, + Aufbereitun $\mathrm{g},+$ Bewertung $\& \mathrm{hl}=\mathrm{ru} \& \mathrm{sa}=\mathrm{X} \& \mathrm{ved}=0 \mathrm{ahUKEwiYofyy} 8$ 8PaAhWI8ywKHWcCDVAQ6AEIJjAA\#v=onepage \&q $=$ Der $\% 20 \mathrm{Nassabbau} \% 20$ Erkundung $\% 2 \mathrm{C} \% 20$ Gewinnung $\% 2 \mathrm{C} \% 20 \mathrm{Aufbereitung} \% 2 \mathrm{C} \% 20$ Bewertung\&f=false $>$ [Accessed 12 February 2017]. 3. Bray, R. N., 2009. A guide to cost standards for dredging equipment. London: CIRIA. Available at: <https:// books.google.com.ua/books?id= EWyygK_T-FAC\& printsec $=$ frontcover $\& \mathrm{hl}=\mathrm{ru} \# \mathrm{v}=$ onepage $\& \mathrm{q} \& \mathrm{f}=$ false $>$ [Accessed 2 February 2017]. 
4. R. N. Bray, ed., Environmental Aspects of dredging. Taylor \& Francis/Balkema. Leiden. Available at: <https://books.google.com.ua/books?id=7xYzciM42Y $\mathrm{C} \&$ printsec $=$ frontcover $\& \mathrm{dq}=$ Environmental + Aspects + of + dredging $\&$ hl $=$ ru\&sa $=$ X\&ved $=0$ ahUKEwjUoLD n88PaAhWDDywKHYnaADMQ6AEIJjAA\#v=onepag e\&q=Environmental\%20Aspects\%20of\%20dredging \& $\mathrm{f}=$ false $>$ [Accessed 5 April 2017].

5. Pavol Rybar, Henrich Hamrak, Jan Kosco, Lucia Domaracka, Dusan Domaracky and Maria Rybarova, 2011. Polymetalicke konkrecie bohatstvo na dne mori a oceanov/Kosice. TU v Kosiciach, Fakulta BERG, Dekanat-Edicne pracovisko. Available at: <https://www.martinus.sk/?uItem=119306> [Accessed 13 March 2017].

6. Gaydin, A. M., Sobko, B. Yu. and Laznikov, O. M., 2016. Mining of flooded deposits of titanium ores. Dnipropetrovsk: Litograf.

7. Bondarenko, A.A., 2012. Mathematical modeling of soil dredger absorption processes in the underwater bottomhole. Metallurgical and Mining Industry, 3, pp. 79-81. 8. Bondarenko, A. A. and Zapara, Ye. S., 2012. Laws of determination of fine materials suction limits in submarine suction dredge face. Naukovyi Visnyk Natsionalnoho Hirnychoho Universytetu, 4, pp. 59-64.

9. Bashtovoy, V. G., Rex, A. G. and Chorny, A. D., 2012. Fluid Mechanics. Minsk: National Technical University. Available at: <https://rep.bntu.by/handle/data/ 24252> [Accessed 27 February 2017].

\section{Теоретичні основи процесу всмоктування пульпи в підводному вибої землесосного снаряда}

\section{А. О. Бондаренко}

Державний вищий навчальний заклад „Національний гірничий університет“, м. Дніпро, Україна, e-mail: Bondarenkoa@nmu.org.ua

Мета. Розробка математичної моделі процесу взаємодії всмоктувального патрубка землесосного снаряда з твердими частинками та формування підводного вибою.

Методика. Для опису руху потоку рідини, що включає тверді частинки, у підводному вибої одиночного всмоктувального патрубка застосоване рівняння нерозривності для ідеальної рідини в полярних координатах. Отримане рішення диференційного рівняння в загальному вигляді. Рух твердих частинок і формування підводного вибою усмоктувального патрубка розглянуто як результат різних показників тиску під частинкою та над нею.

Результати. Виконано математичний опис процесу руху несучого потоку, що переносить тверді частинки в підводній поверхневій зоні всмоктування одиночного усмоктувального патрубка, з використанням рівняння нерозривності для ідеальної рідини, записаний у полярних координатах. Взаємодія всмоктувального патрубка з потоком пульпи описана у вигляді вісесиметричного процесу при постійній у часі функції щільності середовища. Рух твердої частинки в підводному вибої всмоктувального патрубка розглянуто як функція різних показників тиску під частинкою й над нею. Грунтуючись на факті малих швидкостей руху всмоктуваного потоку, отримано вираз для розрахунку радіуса всмоктування твердих частинок і визначення межі зони розмиву при всмоктуванні грунту в підводному вибої всмоктувального патрубка. Ураховано визначальний вплив радіального руху всмоктуваного потоку й незначущість відцентрових сил. Виконана побудова підводної поверхневої зони розмиву одиночного всмоктувального патрубка у вигляді поверхневої межі зони розмиву й межі зони всмоктування зваженого грунту, що складений із частинок кварцу крупністю 0,16 мм при продуктивності всмоктування $800 \mathrm{~m}^{3}$ /год.

Наукова новизна. У результаті розробки математичної моделі на базі рівняння нерозривності, записаного в полярних координатах, встановлено, що радіус усмоктування зважених частинок кварцу крупністю $d=0,15 \ldots .5$ мм у підводному вибої одиночного всмоктувального патрубка прямо пропорційний кореню в четвертому ступеню відношення квадрата продуктивності по пульпі у всмоктувальному патрубку до діаметру розрахункової твердої частинки й косинусу кута нахилу утворюючої зони всмоктування.

Практична значимість. Отримані в роботі аналітичні залежності дозволяють виконувати побудову меж підводного поверхневого вибою й визначати об'єми виймання зернистих грунтів виконавчим органом землесосного снаряда. Це дозволяє обгрунтовувати раціональні конструктивні параметри видобувної машини й технологічні параметри процесу підводного видобутку корисної копалини.

Ключові слова: землесосний снаряд, підводний вибій, розмив, усмоктування

\section{Теоретические основы процесса всасывания пульпы в подводном забое землесосного снаряда}

\section{А. А. Бондаренко}

Государственное высшее учебное заведение „Национальный горный университет“, г. Днепр, Украина, e-mail: Bondarenkoa@nmu.org.ua

Цель. Разработка математической модели процесса взаимодействия всасывающего патрубка землесосного снаряда с твердыми частицами и формирования подводного забоя.

Методика. Для описания движения потока жидкости, включающей твердые частицы, в подводном забое одиночного всасывающего патрубка, применено уравнение неразрывности для идеальной жидкости в полярных координатах. Выполнено решение дифференциального уравнения в общем виде. Движение твердых частиц и формирование подводного забоя всасывающего патрубка рассмо- 
трено как результат разности давлений под частицей и над ней.

Результаты. Выполнено математическое описание процесса движения несущего потока, переносящего твердые частицы в подводной поверхностной зоне всасывания одиночного всасывающего патрубка, с применением уравнения неразрывности для идеальной жидкости, записанное в полярных координатах. Взаимодействие всасывающего патрубка с потоком пульпы описано в виде осесимметричного процесса при постоянной во времени функции плотности среды. Движение твердой частицы в подводном забое всасывающего патрубка рассмотрено как функция разности давлений под частицей и над ней. Основываясь на факте малых скоростей движения всасываемого потока получено выражение для расчета радиуса всасывания твердых частиц и определения границы зоны размыва при всасывании грунта в подводном забое всасывающего патрубка. Учтено определяющее влияние радиального движения всасываемого потока, и незначительность центробежных сил. Выполнено построение подводной поверхностной зоны размыва одиночного всасывающего патрубка в виде поверхностей границы зоны размыва и границы зоны всасывания взвешенного грунта, сложенного из частиц кварца крупностью 0,16 мм при производительности всасывания $800 \mathrm{~m}^{3} /$ час.

Научная новизна. В результате разработки математической модели на базе уравнения неразрывности, записанного в полярных координатах установлено, что радиус всасывания взвешенных частиц кварца крупностью $d=0,15 \ldots 5$ мм в подводном забое одиночного всасывающего патрубка прямо пропорционален корню в четвертой степени отношения квадрата производительности по пульпе во всасывающем патрубке к диаметру расчетной твердой частицы и косинусу угла наклона образующей зоны всасывания.

Практическая значимость. Полученные в работе аналитические зависимости позволяют выполнять построение границ подводного поверхностного забоя и определять объемы выемки зернистых грунтов исполнительным органом землесосного снаряда. Это позволяет обосновать рациональные конструктивные параметры добычной машины и технологические параметры процесса подводной добычи полезного ископаемого.

Ключевые слова: землесосный снаряд, подводный забой, размыв, всасывание

Рекомендовано до публікації докт. техн. наук В. П. Надутим. Дата надходження рукопису 11.04.17. 